\title{
Development and interaction between plant architecture and yield-related traits in winged bean (Psophocarpus tetragonolobus (L.) DC.)
}

\author{
Alberto Stefano Tanzi $(\mathbb{D} \cdot$ Wai Kuan Ho $\cdot$ Festo Massawe $\mathbb{C} \cdot$ Sean Mayes $\mathbb{D}$
}

Received: 11 August 2018/Accepted: 22 January 2019/Published online: 1 February 2019

(C) The Author(s) 2019

\begin{abstract}
Winged bean (P. tetragonolobus (L.) DC.) is a leguminous crop that could contribute towards food security in tropical areas, but whose growth and development is still poorly understood. In order to develop improved individuals for increased green pod and seed productivity, we investigated the factors involved in winged bean plant architecture, development, and their link to a number of yield-related traits. An $F_{2}$ population was generated from the cross between M3 and FP15 Malaysian accessions and assessed under field conditions in Malaysia. The results showed stem length to be mainly influenced by internode length $\left(r_{s}=.80 ; p<.01\right)$, while multiple
\end{abstract}

Electronic supplementary material The online version of this article (https://doi.org/10.1007/s10681-019-2359-8) contains supplementary material, which is available to authorized users.

A. S. Tanzi - W. K. Ho · F. Massawe

Faculty of Science, Biotechnology Research Centre,

School of Biosciences, University of Nottingham

Malaysia, Jalan Broga, 43500 Semenyih,

Selangor Darul Ehsan, Malaysia

A. S. Tanzi - W. K. Ho · F. Massawe - S. Mayes Crops For the Future, Jalan Broga, 43500 Semenyih, Selangor Darul Ehsan, Malaysia

S. Mayes $(\square)$

Faculty of Science, School of Biosciences, University of Nottingham Sutton Bonington Campus, Sutton Bonington, Leicestershire LE12 5RD, UK

e-mail: sean.mayes@nottingham.ac.uk genes could be controlling the number of branches, with an average number of branches in the offspring above the highest parent value. The average length of branches appeared to influence the most the final number of pods per plant $\left(r_{s}=.44 ; p<.001\right)$, while flowering showed potentially transgressive segregation towards earliness, without preventing the potential development of high pod-yielding individuals $\left(r_{s}=-208 ; p=.056\right)$. Taken together, the results reported here shed light on the interaction between morphological, developmental, and yield-related traits, defining potential targets for developing crop ideotypes to direct breeding programmes for this underutilised crop.

Keywords Winged bean Psophocarpus tetragonolobus · Plant breeding · Plant development . Plant architecture $\cdot$ Yield

\section{Introduction}

The second of the Sustainable Development Goals by the United Nations is to end hunger, achieve food security, improved nutrition, and promote sustainable agriculture (UN 2015). To achieve this goal, food production systems have to accommodate the demand for sufficient, safe, and nutritious food by increasing production, diversity, and access. Despite the number 
of edible crops that could contribute, only a handful (wheat, Triticum aestivum; maize, Zea mays; rice, Oryza sativa; soybean, Glycine max) still represent the majority of food production, with a recorded global trend towards more homogeneous agricultural systems (Godfray et al. 2010; Khoury et al. 2014). Such a narrow number of species could undermine food security whenever yield expectations are not matched, due to ever-changing conditions and extreme weather events (Challinor et al. 2014; Ray et al. 2015). Furthermore, an increasing volume of research shows the positive effects of a diversified agriculture on yield stability, sustainability, socio-economics, and human health (Thrupp 2000; Jackson et al. 2007; Hajjar et al. 2008; Chappell and LaValle 2011; Padulosi et al. 2013; Powell et al. 2015; Dwivedi et al. 2016, 2017; Lachat et al. 2017), with a case made for increased vegetable and fruit production (Schreinemachers et al. 2018). If we want to reverse this global trend, we need to encourage and enable the cultivation of a wider range of crops in each geographical area. In this regard, underutilised species offer the advantage of being locally adapted, often to low input systems, with desirable traits to contribute towards a more resilient and diversified agriculture (Weil and Khalil 1986; Padulosi et al. 2013; Pellegrini and Tasciotti 2014; Chivenge et al. 2015; Adhikari et al. 2017).

In the context of Asia and the Pacific area, a leguminous species named "Winged Bean" (Psophocarpus tetragonolobus (L.) DC.) has been cultivated as a vegetable for its green pods, leaves, and tuberous roots, and also as a pulse (NAS 1975; Khan 1976; Lepcha et al. 2017). Like a number of other leguminous species, winged bean has intertwining vines, with a complex plant architecture. Shaped by a main shoot apical meristem and lateral branches, these latter grow according to the number and length of each phytomer (the repetitive unit formed by internode and node), and the fate of each axillary meristem it harbours. In terms of plant architecture, little research has been carried out on winged bean, although there have been a series of experiments focused on the effects of combined temperature and day length regimes on flowering and vegetative biomass accumulation (Herath and Ormrod 1979; Anonymous 1982; Wong 1983; Schiavinato and Válio 1996a). A few investigations aimed at identify influences on plant structure have been published, by testing different physical supports and eventually concluding that trellis was needed in order to promote lateral branching and pod production (Anonymous 1981; Schiavinato and Válio 1996b). However, no investigation has so far described winged bean plant architecture through its component morphological traits (e.g. lateral branching, stem length, node number and internode length), neither has there been research on how these are controlled genetically and inherited. This is despite research in crops like common bean (Phaseolus vulgaris), soybean (G. max), faba bean (Vicia faba), and pea (Pisum sativum) addressing the underlying mechanisms involved in plant architecture changes during domestication, and their impact on productivity and field practices (Lester et al. 1997; Teixeira et al. 1999; Weeden 2007; Ando et al. 2007; Wang and Li 2008; Braun et al. 2012; Andrivon et al. 2013; Ávila et al. 2017; Sun et al. 2018).

Here, we present a study of winged bean plant architecture, carried out on an $\mathrm{F}_{2}$ population obtained from morphologically contrasting parents: M3 and FP15. The aim is to provide a better understanding of the relationships between key morphological traits, their underlying genetic mechanisms, and to determine how variation in plant architecture could impact on pod and seed yield. This could identify the basis for future improvement programmes focused on obtaining high yielding and more amenable winged bean ideotypes, to promote the cultivation of this crop and support efforts to increase agrobiodiversity in tropical areas through adoption and development of endemic species.

\section{Materials and methods}

\section{Plant material and controlled crosses}

Winged bean is considered to have a cleistogamous floral system, which would imply autogamy, with selfpollination taking place before the large flowers open in the morning hours (Karikari 1972; Erskine and Bala 1976; Erskine 1980). Parental individuals were grown in controlled environment rooms $(12 \mathrm{~h}$ photoperiod, $27^{\circ} / 22^{\circ}$ day/night temperature, $65 \% \mathrm{RH}$ minimum) at Crops For the Future (CFF, Semenyih, Malaysia), and crossed following the protocol developed by Erskine and Bala (1976). Half-diallel crosses were performed between the male parent M3 (MARDI, Malaysia), and the emasculated flowers of FP15 (Malaysian, local accession). The male parent did not undergo any 
additional purification, while the female individual was derived from 2 rounds of purification by single seed descent (SSD). Using previously developed genic-SSR markers (Wong et al. 2017), single parents used during crossing were genotyped following the same protocol: M3 reported 17\% of heterozygous loci, while FP15 showed no heterozygosity. From crossing to $F_{2}$ field assessment, parental individuals went through another 2 rounds of self-pollination and SSD purification. This should have further reduced any residual heterozygosity before phenotyping along with the $F_{2}$ population. The same SSR markers were used to validate $\mathrm{F}_{1}$ hybrids obtained from the performed crosses.

\section{Growing conditions}

All plants assessed in field conditions were grown on ridges at the Crops For the Future-Field Research Centre (CFF-FRC, Semenyih, Malaysia) on trellis structures, each made by a net ( $2 \mathrm{~m}$ tall; $1 \mathrm{~m}$ width), with a $1.5 \mathrm{~m}$ distance between consecutive structures, and $1 \mathrm{~m}$ between each ridge. This ensured no competition between adjacent individuals. Seeds were scarified with sand paper in order to obtain more homogenous germination in bags. Plants were then transferred into the field 2 weeks after emergence (a.g.), when stems had reached about $15-20 \mathrm{~cm}$ in height. Fertilizer (NPK 15:15:15) was applied 4 times during the growing season $(5 \mathrm{~g}$ pellet each time, per individual), while pesticide was sprayed approximately every 10 days to prevent pest damage of the main stems (Karate-Syngenta, Switzerland) at $0.5 \mathrm{~mL} / \mathrm{L}$ concentration.

For the first generation: eight $\mathrm{F}_{1}$ hybrids, along with 5 replicates of each parental genotype, were assessed and left free to self-pollinate in a complete randomized design (CRD) from October 2016 to March 2017, in a sandy loam soil ( $\mathrm{pH}$ 5.3). A single hybrid plant was randomly selected for collection of $\mathrm{F}_{2}$ seeds. The $\mathrm{F}_{2}$ segregating population (XB2) derived from this was then assessed between June 2017 and November 2017 in a complete randomized block design (CRBD) with three blocks, each with five replicates of each parent and thirty $F_{2}$ individuals randomly allocated across four ridges; additional $\mathrm{F}_{2}$ individuals were used as border plants. The soil had a sandy loam profile with $\mathrm{pH} 5.0$, while day/night temperatures were $32 \pm .9{ }^{\circ} \mathrm{C}$ and $23 \pm .3{ }^{\circ} \mathrm{C}$ (on site weather station; DeltaT).
Traits recorded

Morphological traits (recorded weekly until 56 days after emergence)

Stem length (StL) was recorded for the main shoot apical meristem, removing individuals that were damaged and had lost apical dominance before the end of morphological measurements; Weekly growth (WGR) was calculated as the increase in each individual stem length since the previous measurement.

Number of nodes (NoN) were counted by starting from the soil to the first true leaves;

Internode length $(\mathrm{InL})$ was recorded for 6th, 10th, 15 th, and 20th internode;

Number of leaves per plant (LPP) was recorded excluding cotyledon leaves (unifoliate);

Leaf width and leaf length (LeW, LeL) were recorded at the largest leaf lamina section, and along the main vein to the tip respectively; measurements were taken on central leaflet on 3 fully expanded leaves per plant, at approximately $1 \mathrm{~m}$ from the ground. Both parental, as well as progeny individuals had deltoid leaflet shape.

Branch number per plant (NoB) was recorded for branches at least $10 \mathrm{~cm}$ in length and carrying at least 1 fully expanded leaf, for the first 10 nodes of the main stem;

Length of branch (LoB) was the average length of all branches longer than $10 \mathrm{~cm}$ per plant, at week 8 after emergence; total sum of branch length (SLB) was calculated by addition of the single branches lengths.

\section{Development traits}

Days to first open flower (DtF) was recorded from the day of emergence (considered when stem length was $2 \mathrm{~cm}$ ) to the first open flower;

Pod maturing time (PMT) was recorded from first open flower to first harvesting of that mature pod.

\section{Yield-related traits}

Harvested mature pods per plant (PPP);

Dry pod length (PoL), and fully-developed seeds per pods (SPP) were recorded using the first 15 harvested pods. Seeds weight was also recorded from each pod, to calculate hundred-seeds weight (HSW). 
For such traits, harvested mature pods were dried in a high-volume oven (Memmert, Germany) at $35{ }^{\circ} \mathrm{C}$ for 4 days before measurements.

\section{Statistical analysis}

Descriptive statistics and data analysis were performed using IBM SPSS ${ }^{\circledR}$ Statistics v25. A ShapiroWilk test was performed to check for normal distribution of trait data (significance level at $=.05$ ), for each parental genotype and progeny population, along with Levene's test for homogeneity of variance. Spearman's bivariate correlation analysis was carried out rather than Pearson's, whenever data did not have a normal frequency distribution. For each MannWhitney $\mathrm{U}$ test we reported median $(M d n)$, test statistic $(U)$, significance $(p)$ and effect size $(r=\mathrm{z}-$ score $/ \sqrt{ }$ (number of observations)).

Two Principal Component Analysis have been performed with IBM SPSS ${ }^{\circledR}$ Statistics v25, and with Genstat v18.

\section{Results}

Plant traits

\section{Stem growth}

Stem length (StL), number of nodes (NoN), and internode length ( $\mathrm{InL})$, followed a normal frequency distribution in both parental genotypes $(p>.05)$. At week 8 ( 56 days after emergence), the male M3 parent showed a significantly shorter stem compared to the female FP15, the latter appearing to grow faster and with longer internodes (Table 1). Such differences between parental phenotypes were also recorded since earlier stages (see Figs. 1 and also supplementary material for more pictures of parental and $F_{2}$ individuals).

StL and NoN in the $F_{2}$ showed a significant deviation from the normal $(p<.001)$, while internode length ( $\mathrm{InL}$ ) had a normal frequency distribution (Fig. 2a). Spearman's correlation found stem length to be significantly $(p<.01)$ correlated with both InL $\left(r_{s}=.80\right)$ and NoN $\left(r_{s}=.58\right)$, and the same results were obtained for weekly growth (WGR). InL appears to be the main factor that influences StL, explaining $60.1 \%$ of variation for the trait from the regression analysis (Fig. 2b). InL also showed the highest coefficient of variation (27\%), followed by StL (25\%), while NoN showed more limited variation between replicates $(11 \%)$.

\section{Secondary branches}

The branch number per plant (NoB) showed a nonnormal frequency distribution in both parents $(p<.05)$, with the female FP15 $(M d n=.00)$ having significantly lower NoB than the male parent M3 $(M d n=2.00) \quad(U=8.50 ; \quad p=.001 ; \quad r=-.80)$ (Table 2).

Also across the $F_{2}$, NoB showed a non-normal distribution $(p<.05)$ (Fig. 3). The average number of branches per plant in the $F_{2}$ was above the highest parent (M3) (Table 2), possibly due also to individuals carrying 6-8 branches (above the maximum of 5 recorded in $\mathrm{M} 3$ individuals). NoB coefficient of variation was $62 \%$, and the trait had a small but significant positive correlation with number of nodes $\left(r_{s}=.29 ; p<.01\right)$.

Between parents, and across the segregating population, there appeared to be differences in the average length of branch (LoB) and the total sum of branch lengths (SLB), the first showing a normal distribution $(p>.05)$. From an earlier stage, M3 individuals

Table 1 Average of traits values related to plant height and growth, at 56 days after emergence, in parents (M3 and FP15) and segregating population (XB2)

\begin{tabular}{lllll}
\hline & Stem length $(\mathrm{StL})(\mathrm{cm})$ & Number of nodes $(\mathrm{NoN})$ & Internode length $(\mathrm{InL})(\mathrm{cm})$ & Weekly growth $($ WGR $)(\mathrm{cm} /$ week $)$ \\
\hline M3 & $200.4 \pm 64.3^{\mathrm{a}}$ & $28.9 \pm 4.6^{\mathrm{a}}$ & $7.2 \pm 1.8^{\mathrm{a}}$ & $27.8 \pm 9.1^{\mathrm{a}}$ \\
FP15 & $322.3 \pm 13.1^{\mathrm{b}}$ & $29.2 \pm 1.8^{\mathrm{a}}$ & $12.9 \pm 1.0^{\mathrm{b}}$ & $44.3 \pm 1.8^{\mathrm{b}}$ \\
$\mathrm{XB} 2\left(\mathrm{~F}_{2}\right)$ & $270.2 \pm 67.5$ & $30.3 \pm 3.3$ & $9.9 \pm 2.65$ & $37.4 \pm 9.7$ \\
\hline
\end{tabular}

Letters $(\mathrm{a}, \mathrm{b})$ for parental values show statistical differences $(p<.05)$ (see "Results" section) 

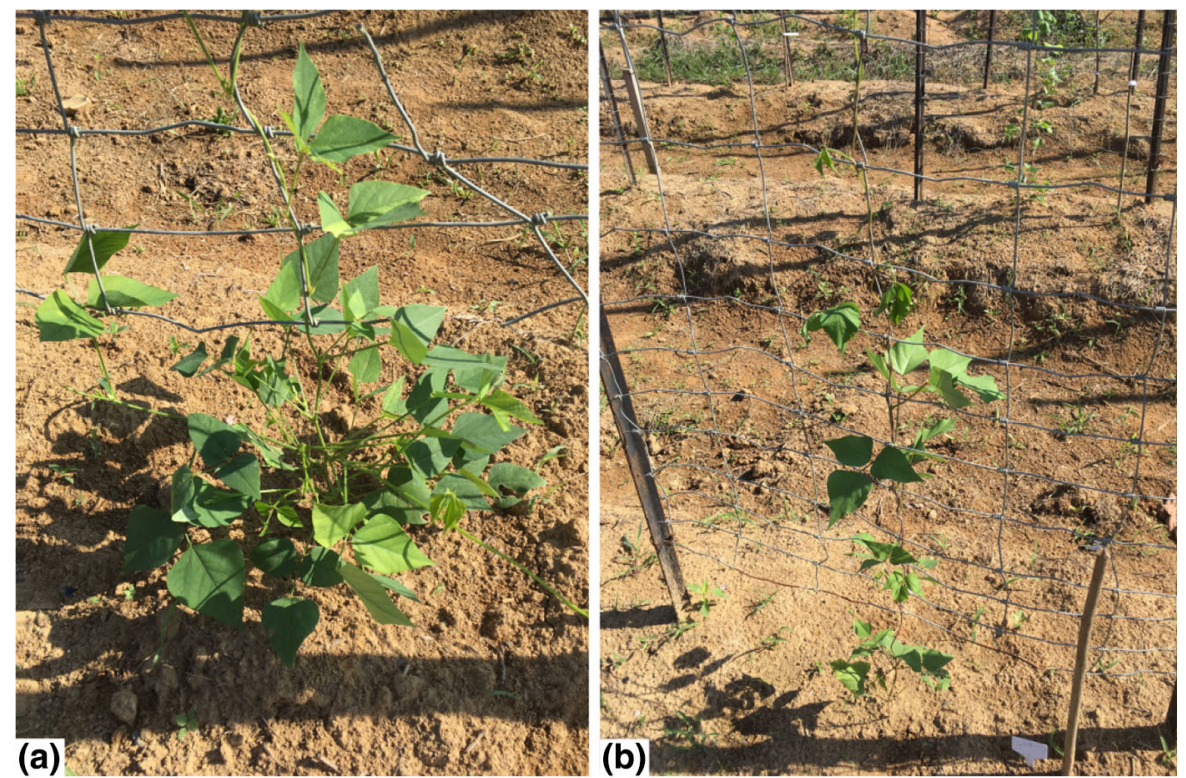

Fig. 1 Parental individuals at about 36 days after emergence. a M3, with a stem length of $95 \mathrm{~cm}, 3$ lateral branches and 27 leaves; b FP15, stem length of $125 \mathrm{~cm}$, no branches, and 15 leaves

(a)

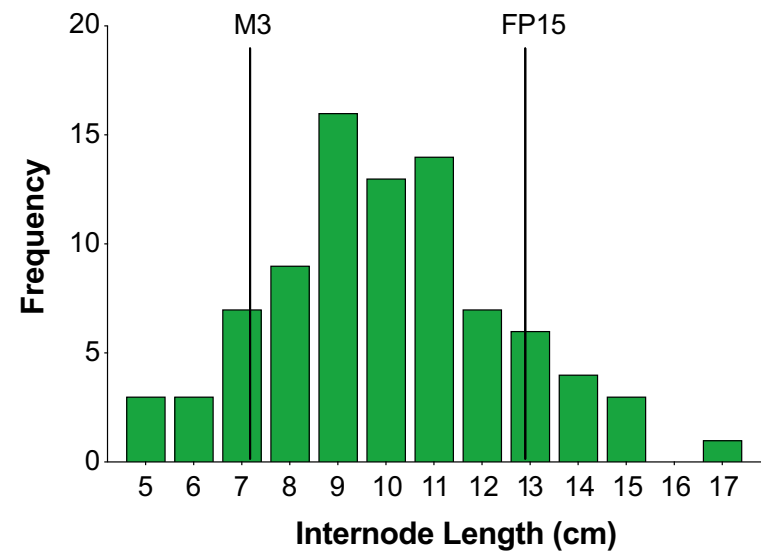

(b)

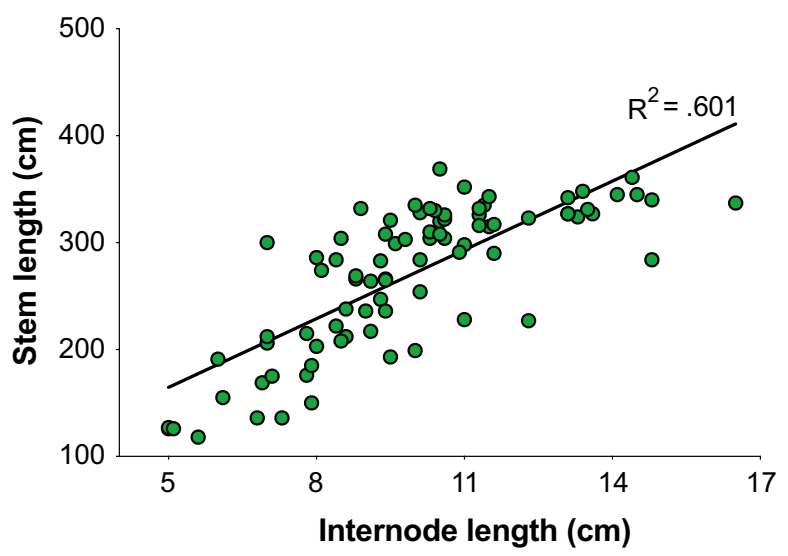

Fig. 2 a Internode length frequency distribution across the $F_{2}$; vertical lines represent mean values for parental genotypes (M3 and FP15). b Stem and internode length regression in $\mathrm{F}_{2}$ (data at 56 days after emergence)

displayed long branches between the first three nodes that overtook, in $43 \%$ of cases, the length to the apical meristem. Long branches were also observed in the $\mathrm{F}_{2}$ population as well (see Table 2), although only $11 \%$ of the individuals generated branches which were longer than the initial SAM. In agreement with this observations, $\mathrm{NoB}$ and $\mathrm{LoB}$ were found to contribute to or correlate with the higher numbers of leaves per plant (LPP) $\left(r_{s}=.79\right.$ and $\left.r=.386\right)$ (see also Fig. 8, in "Secondary branches" section), compared number of nodes alone ( $r_{s}=.34$ respectively; $\left.p<.01\right)$. Variation in branch number per plant did not translate into significant effects on $\operatorname{LoB}\left(r_{s}=.20 ; p=.058\right)$, while both traits contributed to the total sum of branch lengths for individuals $(p<.01)$, with the first having a slightly larger effect $\left(r_{s}=.77\right)$ than the second $\left(r_{s}=.72\right)$. LoB and SLB reported respectively 58 and $68 \%$ coefficients of variation.

Parents showed differences in both LPP and leaf shape-related traits (leaf width, LeW; leaflength LeL): 
Table 2 Lateral branches and their average lengths in the parental and $\mathrm{F}_{2}$ population

\begin{tabular}{lccccrr}
\hline & $\begin{array}{l}\text { Branches } \\
(\mathrm{NoB})\end{array}$ & $\begin{array}{l}\text { Length of branch } \\
(\mathrm{LoB})(\mathrm{cm})\end{array}$ & $\begin{array}{l}\text { Sum of branches } \\
(\mathrm{SLB})(\mathrm{cm})\end{array}$ & $\begin{array}{l}\text { Leaves per plant } \\
(\mathrm{LPP})\end{array}$ & $\begin{array}{l}\text { Leaf width } \\
(\mathrm{LeW})(\mathrm{cm})\end{array}$ & $\begin{array}{l}\text { Leaf length } \\
(\mathrm{LeL})(\mathrm{cm})\end{array}$ \\
\hline $\mathrm{M} 3$ & $2.3 \pm 1.2^{\mathrm{a}}$ & $134.0 \pm 53.3$ & $299.4 \pm 177.1$ & $45.8 \pm 12.9^{\mathrm{a}}$ & $7.4 \pm 1.0^{\mathrm{a}}$ & $8.8 \pm 1.1^{\mathrm{a}}$ \\
$\mathrm{FP} 15$ & $.3 \pm .6^{\mathrm{b}}$ & $12.8 \pm 30.0^{*}$ & $18.9 \pm 46.3^{*}$ & $23.9 \pm 3.5^{\mathrm{b}}$ & $10.0 \pm 1.0^{\mathrm{b}}$ & $13.0 \pm 1.2^{\mathrm{b}}$ \\
$\mathrm{XB} 2\left(\mathrm{~F}_{2}\right)$ & $2.6 \pm 1.6$ & $88.2 \pm 51.2$ & $248.7 \pm 166.9$ & $44.6 \pm 13.2$ & $8.2 \pm 1.2$ & $9.6 \pm 1.5$ \\
\hline
\end{tabular}

Different letters $(a, b)$ for parental values indicate statistically differences (see "Results" section)

*Only 2 individuals developed lateral branches

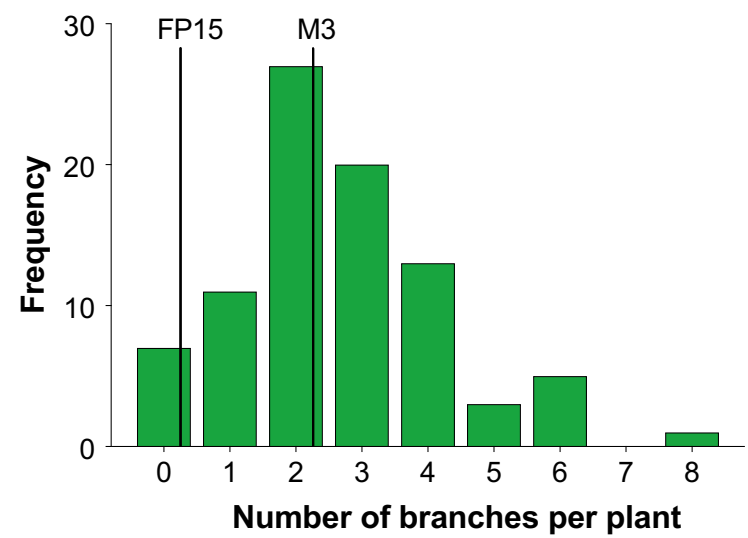

Fig. 3 Number of branches for the first 10 nodes $(\mathrm{NoB})$ for the $\mathrm{F}_{2}$ population at 56 days after emergence $(2.6 \pm 1.6, \mathrm{~N}=84$; Skewness: $657 \pm 0.263)$. Vertical lines represent mean values for parental genotypes (FP15 and M3)

M3 $(M d n=45.5)$ had significantly more leaves than FP15 $(M d n=22.0)(U=4.00 ; p<.001 ; r=-.81)$, but M3 also had narrower $(M d n=7.6)$ and shorter leaves $(M d n=9)$ than FP15 $(M d n=10$ and 13.3 for LeW and LeL respectively) $(U=.50 ; p<.001$; $r=-.84$ for LeW; $U=4.50 ; p<.001 ; r=-.78$ for LeL respectively). Across the $\mathrm{F}_{2}$ population, LPP was found to have a significant $(p<.001)$ inverse correlation with both leaf width $(r=-.36)$ and length $(r=-.41)$.

\section{Principal component analysis (PCA) \\ for morphological traits}

A principal component analysis was carried out in order to investigate whether there were factors that could group correlated morphological traits together. Two components explaining a cumulative variance of $72.8 \%$ were identified: one was associated with traits that define the main vertical growth (stem length, number of nodes and internode length), while the second was related with what determines how "bushy" individuals are (number of branches, length of branch, and leaves per plant). PCA and loading scores from factor rotation analysis using $\mathrm{F}_{2}$ phenotypic data are reported in Fig. 4.

An additional PCA analysis mapped all the parental and $\mathrm{F}_{2}$ individuals, again across two components (see Fig. 5). These latter explained a cumulative variance of $75.8 \%$, with included phenotypic traits showing similar associations to each component as in the first analysis (see loading scores in Fig. 4).

\section{Days from emergence to flowering, and pod development time}

Days to first open flower (DtF) showed significantly earlier open flowers in the female FP15 parent $(M d n=56.5)$ compared to the male parent $(M d n=$ 65.0) $(U=.500 ; p<.01 ; r=-.847)$. The $\mathrm{F}_{2}$ population mostly fell between the two parental averages $(M d n=60.0)$, although there was possible transgressive segregation, with individuals flowering earlier (50 days) as well as later (78 days) than any parental individual (Fig. 6a). Trait distribution deviated from normal $(p<.01)$, with high skewness towards late flowering $(1.38, S E=.26)$. Early flowering appears to be significantly $(p<.01)$ negatively correlated with stem length $\left(r_{s}=-.45\right)$, and branch number per plant $\left(r_{s}=-.25\right)$.

Pod maturing time (PMT) was significantly different between parents, with the female parent FP15 producing mature pods in fewer days $(38.9 \pm 1.8$, $M d n=39.0)$ than $\mathrm{M} 3(53.3 \pm 7.0 ; \quad M d n=52.5)$ $(U=.000 ; p<.01 ; r=-.85)$. The $\mathrm{F}_{2}$ showed a non-normal frequency distribution, with $50.4 \pm 7.0$ days $(M d n=48.0)$ required to produce 


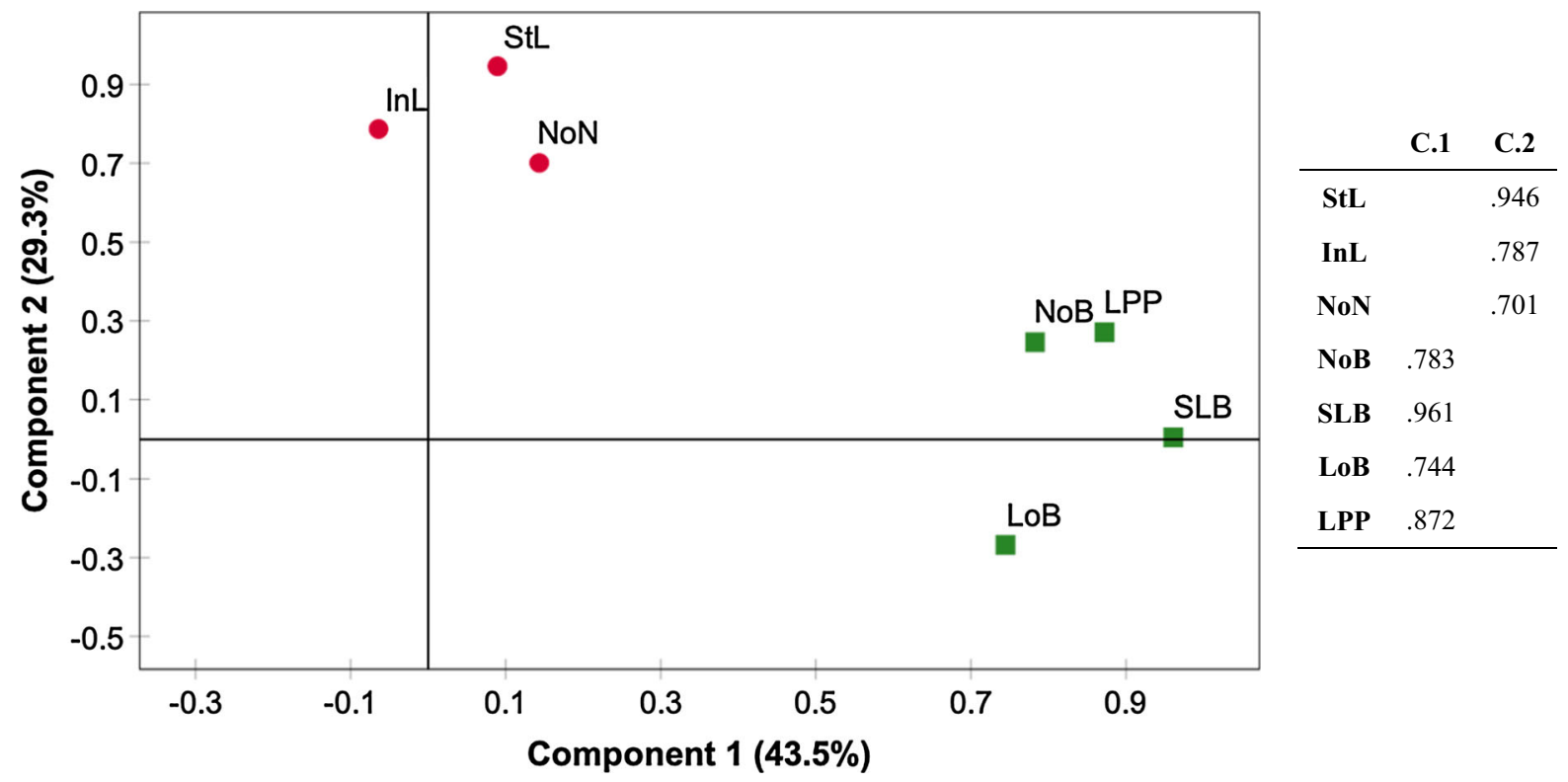

Fig. 4 PCA graph and loading scores for each component (C.1 and C.2) from the rotated component matrix (orthogonal varimax rotation), performed with IBM SPSS using $F_{2}$

mature pods after flowering onset. Only $3.5 \%$ of individuals produced mature pods in 39-40 days, a maturing timing similar to FP15, and a positive correlation was found between DtF and PMT $\left(r_{s}=.25 ; p<.01\right)$ (Fig. 6b).

Yield-related traits

Dry Pod Length (PoL), Pods Per Plant (PPP), Seeds Per Pod (SPP), and Hundred-Seed Weight (HSW) showed normal trait distributions in the parental genotypes $(p>.05)$. FP15 had significantly longer and heavier pods, fewer in number, but each carrying more seeds compared to the male M3 parent $(p<.01)$. On the other hand, HSW did not show a significant difference between the parents $(p=.326)$ (Table 3).

All the mentioned harvest-related traits exhibited normal distribution in the $\mathrm{F}_{2}$ segregating population, except for PPP $(p<.05)$. Noteworthy was the presence of several undeveloped seeds within the $F_{2}$ pods: these had a normal shape, but their development had stopped, leaving them with a diameter less than $1 \mathrm{~mm}$. Pods, however, had an average length between the parental values (Table 3).

Pearson's test revealed a significant positive correlation between PoL and SPP $(r=.67 ; p<.001)$, population data. StL stem length, InL internode length, NoN number of nodes, $N o B$ branch per plant, $S L B$ total sum of branch length, $L o B$ length of branch, $L P P$ number of leaves per plant

confirmed also by a regression analysis $\left[F_{(1,81)}=66.01 ; p<.001 ; \beta=.67\right]$ (Fig. 7).

Pods Per Plant had a significant $(p<.001)$ positive correlation with number of branches $\left(r_{s}=.38\right.$ ) (see also Fig. 8), and length of branch $\left(r_{s}=.44\right)$. However, the effect of incremental branches on final PPP did not appear consistent, while it showed to increase more consistently the number of leaves per plant (Fig. 7). Among the 20 individuals with highest pod productivity (top $25 \%$ of $F_{2}$ population, " $\mathrm{Q}_{3}$ " in Fig. 8): 1 (5\%) had a single branch, $3(15 \%)$ had 2 branches, 8 (40\%) carried only 3 branches, while just 4 individuals (20\%) had 4 branches, and another 4 (20\%) had 6 branches.

On the other hand, all individuals with $3 \mathrm{NoB}$ carried significantly less PPP $(M d n=17)$ than those with $6 \mathrm{NoB} \quad(M d n=24) \quad(U=19.0 ; \quad p<.05$; $r=-.41$ ), and doubling the NoB brought an average $43 \%$ increase in PPP (see Table 4). This seemed supported by significantly higher SLB, which has in turn led to higher LPP values as well (see Table 4 for analysis results, and Fig. 8).

For the remaining yield-related traits, PPP had an inverse, but not significant correlation $\left(r_{s}=-.21\right.$; $p=.056)$ with SPP and HSW. HSW instead had a significant $(p<.01)$ inverse relationship with the 


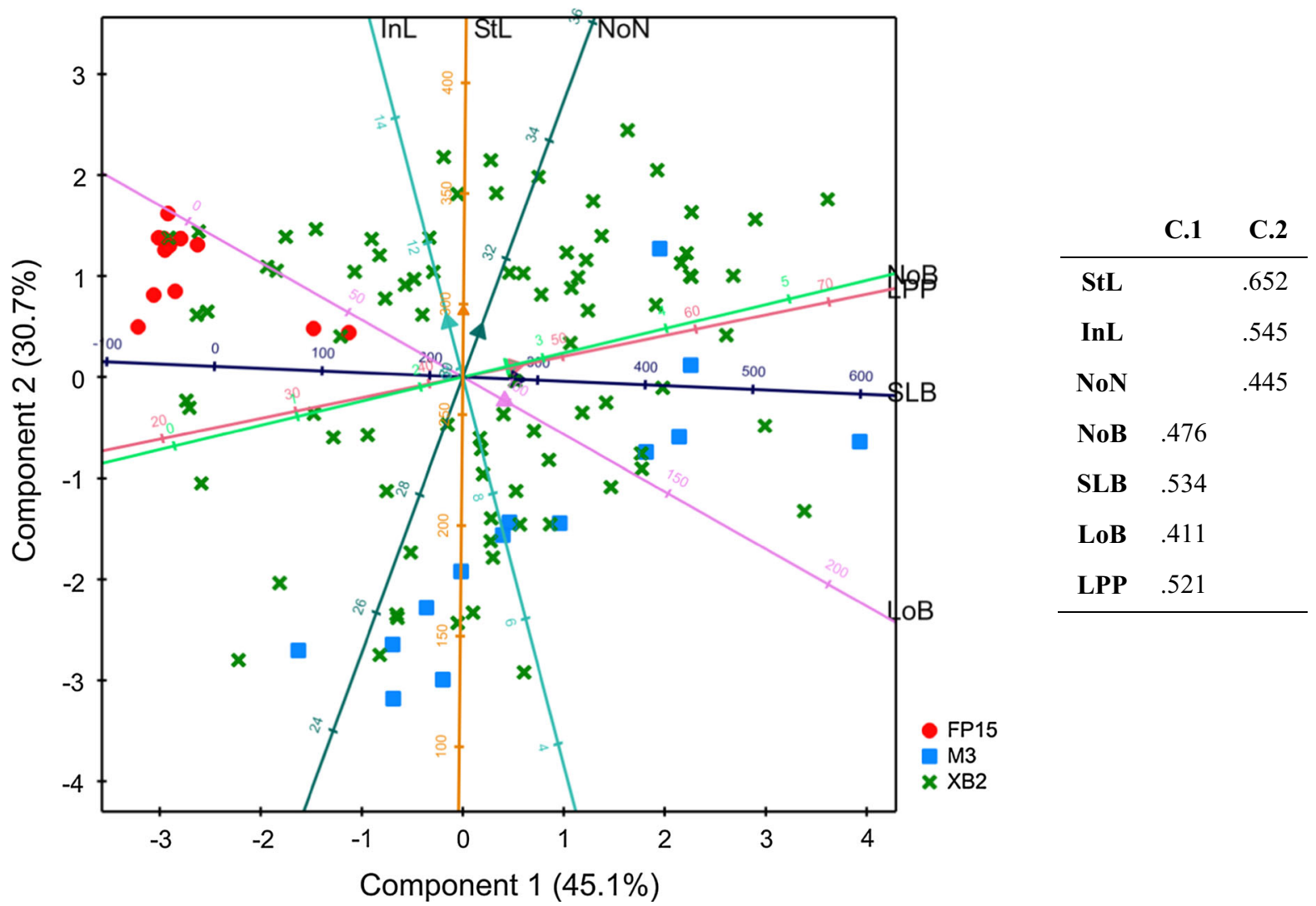

Fig. 5 PCA graph and loading scores for each component (C.1 and C.2) from orthogonal varimax rotation, performed with Genstat v18 using parental (M3 and FP15) and $F_{2}$ (XB2) individuals' phenotypic data. St $L$ stem length, $I n L$ internode

(a)

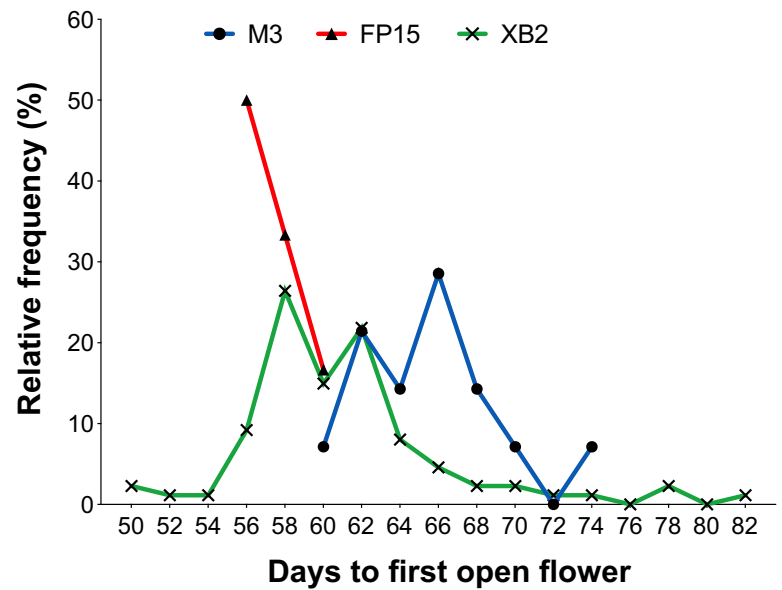

Fig. 6 Days to first open flower (left) and Pod maturing time (right) frequency distribution (\%) for parental (M3; FP15) and $\mathrm{F}_{2}$ (XB2) individuals expressed in days from first open flower to length, $N o N$ number of nodes, $N o B$ branch per plant, $S L B$ total sum of branch length, $L O B$ length of branch, $L P P$ number of leaves per plant

(b)

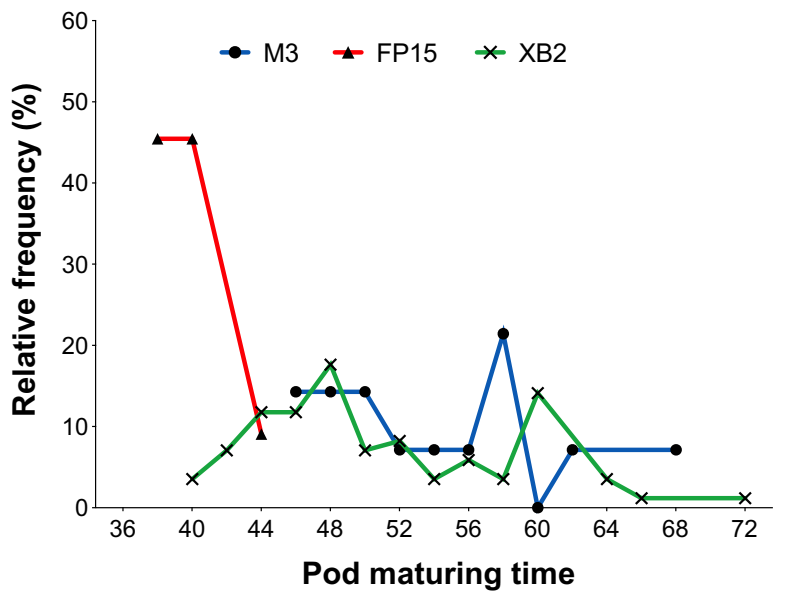

first harvested mature pod. Measurement points at joined to facilitate interpretation only 
Table 3 Harvest traits summary

\begin{tabular}{llccc}
\hline & Pod length $($ PoL) $(\mathrm{cm})$ & Pods per plant $(\mathrm{PPP})$ & Seeds per pod $(\mathrm{SPP})$ & 100-Seed weight $(\mathrm{HSW})(\mathrm{g})$ \\
\hline M3 & $17.7 \pm 2.2^{\mathrm{a}}$ & $14.7 \pm 6.8^{\mathrm{a}}$ & $10.3 \pm 2.0^{\mathrm{a}}$ & $35.7 \pm 5.4$ \\
FP15 & $25.5 \pm 2.2^{\mathrm{b}}$ & $7.8 \pm 2.8^{\mathrm{b}}$ & $13.3 \pm 2.1^{\mathrm{b}}$ & $33.7 \pm 3.5$ \\
XB2 $\left(\mathrm{F}_{2}\right)$ & $18.4 \pm 2.4$ & $14.4 \pm 7.3$ & $8.0 \pm 2.5$ & $39.6 \pm 5.7$ \\
\hline
\end{tabular}

Different letters $(a, b)$ for parental values equals to statistically different values (see "Results"” section)

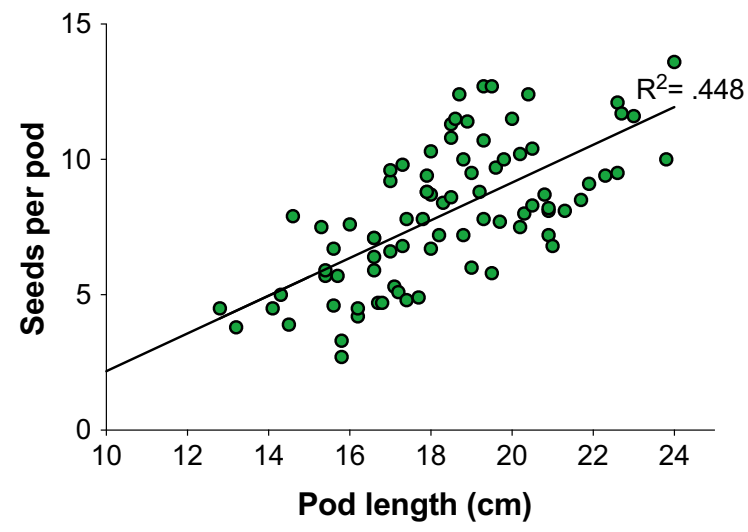

Fig. 7 Regression between fully-developed seeds per pod (SPP) and dry pod length (PoL)

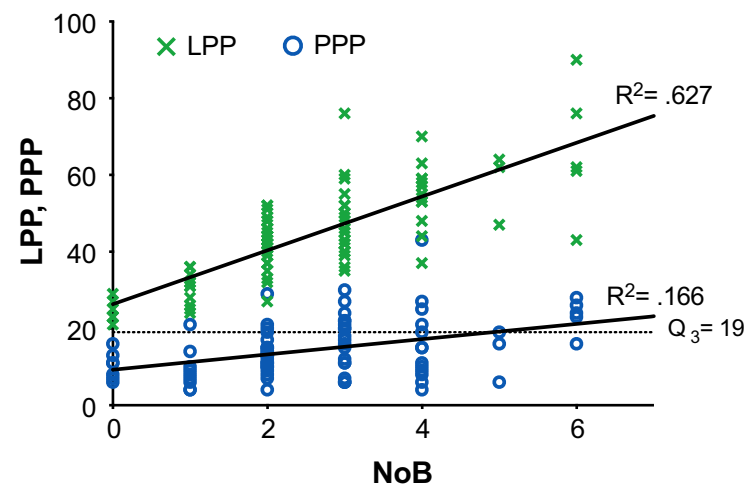

Fig. 8 Regression for number of leaves per plant (LPP) and pods per plant (PPP) against branch number per plant (NoB). The dotted line represents the third quartile $\left(\mathrm{Q}_{3}\right)$ splitting the highest $25 \%$ from the rest of data for PPP across the entire $\mathrm{F}_{2}$ population

number of fully developed seeds per pod $(r=-.28)$. The only significant correlation among yield-related and developmental traits was found between Days to first open flower and HSW $\left(r_{s}=-.23 ; p<.05\right)$.
Pearson's and Spearman's correlations between all measured traits have been reported in supplementary information (Table S1).

\section{Discussion}

Winged bean has a plant architecture determined by the development and growth rate of stem phytomers, and the axillary meristem harboured on each of them. In the present cross, the recombinant population showed how stem length and weekly growth were correlated to internode length. Similar traits, here controlled by multiple genes, have already been a major target during the green revolution, with decreases in height that in some cases translated into increased fertility and yield in crops such as wheat (Harberd and Freeling 1989; Lester et al. 1997; Peng et al. 1999; Sasaki et al. 2002; Hedden 2003; de Saint Germain et al. 2013; Allen et al. 2018). Altering winged bean architecture through internode length could allow selection for plant height independently from the number of nodes. Given the positive correlation between this latter trait and branch number per plant, there is potential to breed for shorter individuals without affecting lateral growth, as is also supported by the two distinct components found in both PCA. When using phenotypic data from parental and $F_{2}$ individuals (Fig. 5), PCA also showed a pattern in agreement with the profiles emerged from the reported values, with FP15 having longer main stems and internodes, and with fewer and shorter branches that result in a less "bushy" individuals. In contrast, M3 showed shorter architecture, but with more and longer branches leading to higher LPP. The M3 individuals also showed a relatively larger phenotypic variation, perhaps underlied by higher genetic variation as compared to the female parent. 
Table 4 Comparison for selected morphological traits between 3-branch and 6-branch individuals, with results from single MannWhitney U tests

\begin{tabular}{|c|c|c|c|c|c|}
\hline & $\mathrm{LoB}(\mathrm{cm})$ & SLB $(\mathrm{cm})$ & LPP & PPP & SPP \\
\hline $\begin{array}{l}3 \mathrm{NoB} \\
20 \text { individuals }\end{array}$ & $113.4 \pm 49.2$ & $339.9 \pm 147.7$ & $47.7 \pm 9.7$ & $16.4 \pm 7.3$ & $8.1 \pm 3.2$ \\
\hline $\begin{array}{l}6 \mathrm{NoB} \\
5 \text { individuals }\end{array}$ & $86.7 \pm 9.3$ & $520.0 \pm 56.2$ & $66.4 \pm 17.6$ & $23.4 \pm 4.6$ & $8.1 \pm 1.9$ \\
\hline Change (\%) & -24 & 53 & 39 & 43 & -1 \\
\hline Mann-Whitney U test $(p)$ & .209 & $.014 *$ & $.017 *$ & $.042 *$ & .915 \\
\hline Effect size $(r)$ & & .49 & .48 & .41 & \\
\hline
\end{tabular}

$N o B$ branch per plant, $L O B$ length of branch, $S L B$ total sum of branch length, $L P P$ number of leaves per plant, $P P P$ mature pods per plant, $S P P$ seeds per pod. *Significant at .05 level

Branching, here described through number and length of lateral branches, is a mechanism controlled by multiple endogenous factors, and their interactions with the environment at different development stages. Across the $\mathrm{F}_{2}$ population, branch number per plant appeared multigenic, with a mean above the parent carrying the highest number. The average value, above the highest parent (M3), appears in agreement with what was previously reported by Eagleton (Eagleton 1983) across $3 \mathrm{~F}_{2}$ s from 3 diallel crosses assessed in 2 different environments (Malaysia and Australia). In that study, the NoB trait reported the highest inheritance across the analysed traits $\left(h^{2}=65.5\right.$, estimate based on variance components using Jinks-Hayman diallel analysis of $F_{1}$ generation) along with a proposed additive gene effect with dominance directed towards higher branch number, and minimal environmental effect, later confirmed across three $F_{2}$ populations.

For the relationship between branch number per plant and pods per plant, the overall trend would suggest that more branches lead to more pods. However, the presence of high pod-yielding individuals with $2-3$ branches points towards the possibility of having fewer branches and maintaining high pods per plant. Increasing the length of branch, actually, could bring a greater benefit to final pod number, as there was a stronger correlation between these two traits than between NoB and PPP. A possible explanation for these results could be the presence, on each branch, of the unreproductive nodes that are produced below the growing shoot meristem. This could become a significant limitation in shorter branches and result in vegetative biomass growth, without contributing to final pod development and yield. Therefore, a possible ideotype for winged bean could include a low number of lateral branches, but each with higher average length (length of branch, LoB). Such a phenotype would harbour more reproductive organs, while limiting vegetative biomass growth that follows from higher NoB. This could also reduce the number of leaves, a mechanism that could be compensated at least partially by the observed increase in leaf size. Furthermore, from the open flower stage to a growing pod stage there are traits, such as the rate of successful fertilization, or pod photosynthetic activity, that could also be targeted in breeding programmes to improve pod productivity, without having to rely on morphological traits alone. Examples for this could be the individual XB2-147 and XB2-211: the first having 3 lateral branches on average $138 \mathrm{~cm}$ long, and producing 27 pods while having 40 leaves; the second, carrying 6 branches, on average $98 \mathrm{~cm}$ long, and producing one additional pod (28 in total) but with an additional 21 leaves (61 in total). Another individual, XB-237, showed a relatively short structure (stem length of $127 \mathrm{~cm}$ ), 3 branches on average $101 \mathrm{~cm}$ long, producing 22 pods with 52 leaves. Selection, and further investigations, could look into how to breed for individuals with a high pod productivity and curbed vegetative growth.

In the present study were also reported individuals having branches departing from low nodes and able to grow above the main stem, with axillary meristems behaving as if there was a loss of the main shoot apical dominance. This phenomenon, possibly inherited 
from the M3 parent, was only previously reported in winged bean individuals where apical dominance was probably lost due to horizontal, unsupported growth of the main shoot (Schiavinato and Válio 1996b). In the present case it could be rather due to changes in regulatory mechanisms acting on axillary meristem growth. These could include gene expression regulatory networks, hormones, secondary messengers, or acropetal signals from root system (Foo et al. 2001; Symons et al. 2002; Mason et al. 2014; Wang 2014; Teichmann and Muhr 2015), and further studies could elucidate the underlying mechanism involved here.

Days to first open flower appears to be polygenic, with the $F_{2}$ population average closer to the laterflowering parent M3. This trait, however, showed transgressive segregation in both directions, with individuals flowering earlier and later than the earliest (FP15) and latest (M3) parental genotype respectively. The negative correlations reported between DtF and branch number per plant would encourage selection of early flowering individuals, which are unaffected in structure and capable of yielding a great number of pods, and seed yield. At the same time, early flowering individuals were also shown to produce mature pods earlier (pod maturing time), eventually shortening the time from emergence to harvest. An example could be XB2-75, reporting a DtF value of 55, PMT of 47 days, 2 lateral branches and producing 21 pods about $21 \mathrm{~cm}$ long. Some of the $F_{2}$ individuals with potentially useful combinations of morphological, developmental, and yield-related traits are reported in Table 5. Future studies could investigate such combinations in later generations, and further elucidate the effects on green pod and seed yield.

Pod length and seeds per pod were found to be positively correlated, indicating that pod length could be used as a direct target trait for increasing seed yield. This correlation is reported although the $F_{2}$ showed a relatively low seeds per pod mean, below the lower parent (M3) despite having similar pod lengths. Such an observation is consistent with the previous $\mathrm{F}_{1}$ hybrids ( $5.5 \pm .9$ seeds per pod $)$, while hundred-seed weight appeared consistently higher in both generations, following the negative correlation between these two traits. The mechanism controlling the development of pod morphology could be, at least partially, independent from the final number of fully developed seeds inside the pod itself. Undeveloped seeds appeared, indeed, as if arrested early during their

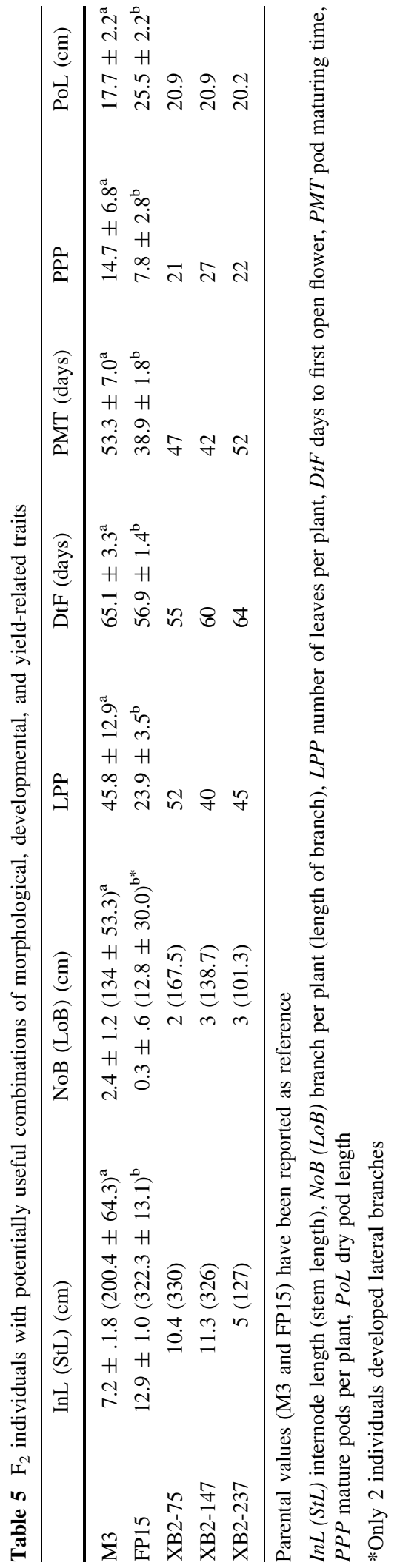


filling, perhaps after the switch to filial control over seed development (Weber et al. 2005).

Finally, the major component of seed yield, here PPP, SPP, and HSW usually have negative correlations between each other, likely because they act as competing sink for dry matter partitioning (Cai et al. 2016). In the present study such correlations were found as well, although only HSW and SPP reported significant correlation values. An increase in pods per plant and seeds per pod could be the way towards higher pod and seed-yielding winged bean individuals, while further studies could focus on assimilate partitioning during pod filling.

\section{Conclusions}

Winged bean has received limited focus for the improvement of plant architecture, despite its broad cultivation and potential benefits in Asia and the Pacific areas food systems. The population reported here demonstrated that there is the possibility to improve and select for traits that most effect the cultivation of this leguminous species. Shorter individuals, with fewer but longer lateral branches, yielding pods and seed in less time might be obtained through selection without having these traits affecting each other negatively. Further studies can focus on the mechanisms involved in the release of dormant axillary meristems, different planting densities, and investigate more in depth the correlation between yield-related traits and final harvest.

Acknowledgements This work was financially supported by Crops for the Future (CFF), and the University of Nottingham Malaysia (UNM) through the CFF-UNM Doctoral Training Partnership scheme. Seeds were obtained from the Malaysian Agricultural Research and Development Institute (MARDI), and by our collaborators in Malaysia. The authors would like to thank Dr Graham Eagleton for helping in the design of the trellis structure, and the team at the Field Research Centre (CFF-FRC) for helping in setting up the experimental plots.

\section{Compliance with ethical standards}

Conflict of interest All authors declare that they have no conflict of interest.

Open Access This article is distributed under the terms of the Creative Commons Attribution 4.0 International License (http:// creativecommons.org/licenses/by/4.0/), which permits unrestricted use, distribution, and reproduction in any medium, provided you give appropriate credit to the original author(s) and the source, provide a link to the Creative Commons license, and indicate if changes were made.

\section{References}

Adhikari L, Hussain A, Rasul G (2017) Tapping the potential of neglected and underutilized food crops for sustainable nutrition security in the mountains of Pakistan and Nepal. Sustain 9:291. https://doi.org/10.3390/su9020291

Allen LH, Zhang L, Boote KJ, Hauser BA (2018) Elevated temperature intensity, timing, and duration of exposure affect soybean internode elongation, mainstem node number, and pod number per plant. Crop J 6:148-161. https://doi.org/10.1016/j.cj.2017.10.005

Ando K, Grumet R, Terpstra K, Kelly JD (2007) Manipulation of plant architecture to enhance crop disease control. CAB Rev Perspect Agric Vet Sci Nutr Nat Resour 2:1053-1063. https://doi.org/10.1079/PAVSNNR20072026

Andrivon D, Giorgetti C, Baranger A et al (2013) Defining and designing plant architectural ideotypes to control epidemics? Eur J Plant Pathol 135:611-617. https://doi.org/ 10.1007/s10658-012-0126-y

Anonymous (1981) The winged bean flyer (3 No. 2). International Documentation Centre for the Winged Bean Agricultural Information Bank of Asia, Laguna

Anonymous (1982) The winged bean flyer (4 No. 1). International Documentation Centre for the Winged Bean Agricultural Information Bank of Asia, Laguna

Ávila CM, Ruiz-Rodríguez MD, Cruz-Izquierdo S et al (2017) Identification of plant architecture and yield-related QTL in Vicia faba L. Mol Breed 37:88. https://doi.org/10.1007/ s11032-017-0688-7

Braun N, de Saint Germain A, Pillot J-P et al (2012) The pea TCP transcription factor PsBRC1 acts downstream of strigolactones to control shoot branching. Plant Physiol 158:225-238. https://doi.org/10.1104/pp.111.182725

Cai G, Yang QQ, Chen H et al (2016) Genetic dissection of plant architecture and yield-related traits in Brassica napus. Sci Rep 6:21625. https://doi.org/10.1038/srep21625

Challinor AJ, Watson J, Lobell DB et al (2014) A meta-analysis of crop yield under climate change and adaptation. Nat Clim Change 4:287-291. https://doi.org/10.1038/ nclimate 2153

Chappell MJ, LaValle LA (2011) Food security and biodiversity: can we have both? an agroecological analysis. Agric Hum Values 28:3-26. https://doi.org/10.1007/s10460-0099251-4

Chivenge P, Mabhaudhi T, Modi AT, Mafongoya P (2015) The potential role of neglected and underutilised crop species as future crops under water scarce conditions in Sub-Saharan Africa. Int J Environ Res Public Health 12:5685-5711. https://doi.org/10.3390/ijerph120605685

de Saint Germain A, Ligerot Y, Dun EA et al (2013) Strigolactones stimulate internode elongation independently of gibberellins. Plant Physiol 163:1012-1025. https://doi.org/ 10.1104/pp.113.220541 
Dwivedi SL, Ceccarelli S, Blair MW et al (2016) Landrace germplasm for improving yield and abiotic stress adaptation. Trends Plant Sci 21:31-42. https://doi.org/10.1016/j. tplants.2015.10.012

Dwivedi SL, Lammerts van Bueren ET, Ceccarelli S et al (2017) Diversifying food systems in the pursuit of sustainable food production and healthy diets. Trends Plant Sci 22:842-856. https://doi.org/10.1016/j.tplants.2017.06.011

Eagleton GE (1983) Evaluation of genetic resources in the winged bean (Psophocarpus tetragonolobus (L.) DC.) and their utilisation in the development of cultivars for higher latitudes. University of Western Australia

Erskine W (1980) Measurements of the cross-pollination of winged bean in Papua New Guinea. SABRAO J 12:11-14

Erskine W, Bala AA (1976) Crossing technique in winged bean. Trop Grain Legum Bull 6:32-35

Foo E, Turnbull CG, Beveridge CA (2001) Long-distance signaling and the control of branching in the rms 1 mutant of pea. Plant Physiol 126:203-209. https://doi.org/10.1104/ pp.126.1.203

Godfray HCJ, Beddington JR, Crute IR et al (2010) Food security: the challenge of feeding 9 billion people. Science 327:812-818. https://doi.org/10.1126/science.1185383

Hajjar R, Jarvis DI, Gemmill-Herren B (2008) The utility of crop genetic diversity in maintaining ecosystem services. Agric Ecosyst Environ 123:261-270. https://doi.org/10. 1016/j.agee.2007.08.003

Harberd NP, Freeling M (1989) Genetics of dominant gibberellin-insensitive dwarfism in maize. Genetics 121:827-838

Hedden P (2003) The genes of the green revolution. Trends Genet 19:5-9. https://doi.org/10.1016/S01689525(02)00009-4

Herath HMW, Ormrod DP (1979) Effects of temperature and photoperiod on winged beans [Psophocarpus tetragonolobus (L.) DC.]. Ann Bot 43:729-736. https://doi.org/ 10.1093/oxfordjournals.aob.a085686

Jackson LE, Pascual U, Hodgkin T (2007) Utilizing and conserving agrobiodiversity in agricultural landscapes. Agric Ecosyst Environ 121:196-210. https://doi.org/10.1016/j. agee.2006.12.017

Karikari SK (1972) Pollination requirements of winged beans (Psophocarpus spp. Neck) in Ghana. Ghana J Agric Sci 5:235-239

Khan TN (1976) Papua New Guinea: a centre of genetic diversity in winged bean (Psophocarpus tetragonolobus (L.) DC.). Euphytica 25:693-705. https://doi.org/10.1007/ BF00041608

Khoury CK, Bjorkman AD, Dempewolf H et al (2014) Increasing homogeneity in global food supplies and the implications for food security. Proc Natl Acad Sci 111:4001-4006. https://doi.org/10.1073/pnas.1313490111

Lachat C, Raneri JE, Smith KW et al (2017) Dietary species richness as a measure of food biodiversity and nutritional quality of diets. Proc Natl Acad Sci 115:201709194. https://doi.org/10.1073/pnas.1709194115

Lepcha P, Egan AN, Doyle JJ, Sathyanarayana N (2017) A review on current status and future prospects of winged bean (Psophocarpus tetragonolobus) in tropical agriculture. Plant Foods Hum Nutr 72:225-235. https://doi.org/ $10.1007 / \mathrm{s} 11130-017-0627-0$
Lester DR, Ross JJ, Davies PJ, Reid JB (1997) Mendel's stem length gene (Le) encodes a gibberellin 3 beta-hydroxylase. Plant Cell 9:1435-1443. https://doi.org/10.1105/tpc.9.8. 1435

Mason MG, Ross JJ, Babst BA et al (2014) Sugar demand, not auxin, is the initial regulator of apical dominance. Proc Natl Acad Sci 111:6092-6097. https://doi.org/10.1073/ pnas. 1322045111

NAS (1975) The winged bean: a high-protein crop for the humid tropics. National Academy of Sciences, Washington, DC

Padulosi S, Thompson J, Rudebjer P (2013) Fighting poverty, hunger and malnutrition with neglected and underutilized species: needs, challenges and the way forward. Biodiversity International, Rome

Pellegrini L, Tasciotti L (2014) Crop diversification, dietary diversity and agricultural income: empirical evidence from eight developing countries. Can J Dev Stud 35:211-227. https://doi.org/10.1080/02255189.2014.898580

Peng J, Richards DEDE, Hartley NMNM et al (1999) "Green revolution" genes encode mutant gibberellin response modulators. Nature 400:256-261. https://doi.org/10.1038/ 22307

Powell B, Thilsted SH, Ickowitz A et al (2015) Improving diets with wild and cultivated biodiversity from across the landscape. Food Secur 7:535-554. https://doi.org/10.1007/ s12571-015-0466-5

Ray DK, Gerber JS, MacDonald GK, West PC (2015) Climate variation explains a third of global crop yield variability. Nat Commun 6:1-9. https://doi.org/10.1038/ncomms6989

Sasaki A, Ashikari M, Ueguchi-Tanaka M et al (2002) Green revolution: a mutant gibberellin-synthesis gene in rice. Nature 416:701-702. https://doi.org/10.1038/416701a

Schiavinato MA, Válio IFM (1996a) Influence of photoperiod and temperature on the development of winged bean plants. RBrasFisiolVeg 8:105-110

Schiavinato MA, Válio IFM (1996b) Influence of staking on development of winged bean plants. RBrasFisiolVeg 8:99-103

Schreinemachers P, Simmons EB, Wopereis MCS (2018) Tapping the economic and nutritional power of vegetables. Glob Food Sec 16:36-45. https://doi.org/10.1016/j.gfs. 2017.09.005

Sun Z, Su C, Yun J et al (2018) Genetic improvement of the shoot architecture and yield in soya bean plants via the manipulation of GmmiR156b. Plant Biotechnol J. https:// doi.org/10.1111/pbi.12946

Symons GM, Ross JJ, Murfet IC (2002) The bushy pea mutant is IAA-deficient. Physiol Plant 116:389-397. https://doi.org/ 10.1034/j.1399-3054.2002.1160315.x

Teichmann T, Muhr M (2015) Shaping plant architecture. Front Plant Sci 6:1-18. https://doi.org/10.3389/fpls.2015.00233

Teixeira FF, Ramalho MAP, De Fátima Barbosa Abreu Â (1999) Genetic control of plant architecture in the common bean (Phaseolus vulgaris L.). Genet Mol Biol 22:577-582. https://doi.org/10.1590/S1415-47571999000400019

Thrupp LA (2000) Linking agricultural biodiversity and food security: the valuable role of agrobiodiversity for sustainable agriculture. Int Aff 76:283-297. https://doi.org/10. $1111 / 1468-2346.00133$

UN (2015) Transforming our world: the 2030 agenda for sustainable development (A/RES/70/1). United Nations 
Wang J-W (2014) Regulation of flowering time by the miR156mediated age pathway. J Exp Bot 65:4723-4730. https:// doi.org/10.1093/jxb/eru246

Wang Y, Li J (2008) Molecular basis of plant architecture. Annu Rev Plant Biol 59:253-279. https://doi.org/10.1146/ annurev.arplant.59.032607.092902

Weber H, Borisjuk L, Wobus U (2005) Molecular physiology of legume seed development. Annu Rev Plant Biol 56:253-279. https://doi.org/10.1146/annurev.arplant.56. 032604.144201

Weeden NF (2007) Genetic changes accompanying the domestication of Pisum sativum: is there a common genetic basis to the "domestication syndrome" for legumes? Ann Bot 100:1017-1025. https://doi.org/10.1093/aob/mcm122
Weil RR, Khalil NA (1986) Salinity tolerance of winged bean as compared to that of soybean. Agron J 78:67. https://doi. org/10.2134/agronj1986.00021962007800010015x

Wong KC (1983) Effects of day length, temperature, light intensity and applied growth substances on the growth, flowering and tuberization of winged bean (Psophocarpus tetragonolobus (L.) DC.). Universiti Putra Malaysia

Wong Q, Tanzi AS, Ho W et al (2017) Development of genebased SSR markers in winged bean (Psophocarpus tetragonolobus (L.) DC.) for diversity assessment. Genes 8:100. https://doi.org/10.3390/genes8030100

Publisher's Note Springer Nature remains neutral with regard to jurisdictional claims in published maps and institutional affiliations. 